\title{
Article/Artigo
}

\section{Increased detection of schistosomiasis with Kato-Katz and SWAP- IgG-ELISA in a Northeastern Brazil low-intensity transmission area}

\author{
Aumento da deteç̧ão da esquistossomose com Kato-Katz e SWAP-IgG-ELISA, em área de \\ baixa endemicidade, no nordeste do Brasil
}

\author{
Teiliane Rodrigues Carneiro, ${ }^{1,2}$, Marta Cristhiany Cunha Pinheiro ${ }^{1,2}$, Sara Menezes de Oliveira ${ }^{2}$, Ana Lúcia de \\ Paula Hanemann ${ }^{1,2}$, José Ajax Nogueira Queiroz ${ }^{2}$ and Fernando Schemelzer Moraes Bezerra ${ }^{1,2,3}$
}

\begin{abstract}
Introduction: The laboratory diagnosis of schistosomiasis is based mainly on the detection of parasite eggs in stool samples through the Kato-Katz (KK) technique, reading one slide by test. However, a widely known limitation of parasitological methods is reduced sensitivity, particularly in low endemic areas. Methods: To increase sensitivity, we conducted further slide readings from the same stool sample using the parasitological method associated with a serological test. We used the KK method (three slides) and the IgG anti-Schistosoma mansonienzyme-linked immunosorbent assay (ELISA) technique to diagnose schistosomiasis in low endemic areas in the Brazilian State of Ceará. Fecal samples and sera from 250 individuals were analyzed. Results: Sixteen percent and $47.2 \%$ of samples were positive in parasitological tests and serological tests, respectively. Parasitological methods showed that 32 (80\%) individuals tested positive on the first slide, $6(15 \%)$ on the second slide, and $2(5 \%)$ on the third. The performance of the ELISA test in the diagnosis, using the KK method as diagnostic reference, showed a negative predictive value of $100 \%$, with specificity and positive predictive values of $62.8 \%$ and $33.9 \%$, respectively. Conclusions: In this study, the increase from one to three slides analyzed per sample using the KK technique was shown to be a useful procedure for increasing the diagnostic sensitivity of this technique.
\end{abstract}

Keywords: Schistosomiasis. Diagnosis. Schistosoma mansoni. Kato-Katz. ELISA.

\section{RESUMO}

Introdução: $\mathrm{O}$ diagnóstico laboratorial da esquistossomose é baseada principalmente na detecção de ovos do parasito nas fezes, realizada pela técnica de Kato-Katz (KK), com a leitura de uma lâmina por teste. No entanto, uma limitação conhecida dos métodos coproscópicos é a reduzida sensibilidade, especialmente nas áreas de baixa endemicidade. Métodos: A fim de reduzir essa limitação, realizamos mais leituras da mesma amostra de fezes pelo método coproscópico e associamos a um teste sorológico. Utilizamos o método de KK (três lâminas) e a técnica de IgG-ELISA, buscando aumentar a sensibilidade do diagnóstico da esquistossomose em área de baixa endemicidade, no Estado Brasileiro do Ceará. Amostras de fezes e soro de 250 indivíduos foram analisadas. Resultados: Destas, 40 e 118 foram positivas nos testes coproscópico e sorológico, respectivamente. Na coproscopia, 32 (80\%) indivíduos tiveram testes positivos na primeira lâmina, $6(15 \%)$ na segunda e $2(5 \%)$ apenas na terceira lâmina. $\mathrm{O}$ desempenho do teste de ELISA no diagnóstico utilizando-se o método KK como referência de diagnóstico, demonstrou valor preditivo negativo de $100 \%$ mas a especificidade e o valor preditivo positivo foram de $62,8 \%$ e $33,9 \%$, respectivamente. Conclusões: Neste estudo, o aumento de uma para três lâminas analisadas por amostra pelo KK, mostrou ser um procedimento útil para o aumento da sensibilidade diagnóstica desta técnica.

Palavras-chaves: Esquistossomose. Diagnóstico. Schistosoma mansoni. Kato-Katz. ELISA.

1. Departamento de Análises Clínicas e Toxicológicas, Faculdade de Farmácia, Odontologia e Enfermagem, Universidade Federal do Ceará, Fortaleza, CE. 2. Departamento de Patologia e Medicina Legal, Universidade Federal do Ceará, Fortaleza, CE. 3. Departamento de Saúde Comunitária, Universidade Federal do Ceará, Fortaleza, CE.

Address to: Dr. Fernando Schemelzer Moraes Bezerra. Depto. Análises Clínicas e Toxicológicas/FFOE/UFC. Rua Capitão Francisco Pedro 1210, 60430-370 Fortaleza, CE, Brasil.

Fax: $55853366-8242$

e-mail: bezerra@ufc.br

Received in 17/09/2011

Accepted in 20/12/2011

\section{INTRODUCTION}

Schistosomiasis is still considered one of the most important chronic parasitic diseases in tropical regions, affecting approximately 200 million people worldwide despite the continued implementation of control measures ${ }^{1}$. In Northeast Brazil, some isolated foci of intestinal schistosomiasis remain, with low intensity of transmission and, consequently, low parasite burden. Current data from the Schistosomiasis Control Program, or Programa de controle da esquistossomose (PCE), characterize the State of Ceará, Brazil, as an area of low prevalence, but indicate that this state has the locality with the highest positivity rate for schistosomiasis (Planalto do Cajueiro in the municipality of Maranguape), where the prevalence was $8.5 \%$ in 2006 and $13.8 \%$ in 2007. The World Health Organization recommends the Kato-Katz (KK) technique ${ }^{2}$ as the standard diagnostic method for intestinal schistosomiasis, as it is simple and low cost, and the intensity of infection can be estimated ${ }^{3}$. However, KK smears and other parasitological methods frequently fail to detect low-intensity infections ${ }^{4}$, which leads to an underestimation of the actual prevalence of disease $\mathrm{e}^{5,6}$.

To overcome this limitation, examination of a larger quantity of fecal material is necessary ${ }^{7}$. By increasing the number of KK smears per sample and the number of stool samples taken, it is possible to increase sensitivity considerably ${ }^{8}$. It is worth noting that the control of schistosomiasis-related morbidity has become feasible due to the development of single-dose oral drugs such as oxamniquine and praziquantel, which are given to heavily infected patients (high worm burden) who are easily detected by field-applicable parasitological methods. With the transition to lower morbidity, more sensitive diagnostic methods are needed ${ }^{9}$. In this context, the enzyme-linked immunosorbent assay (ELISA) immunological technique has been proposed for use in the $\mathrm{PCE}^{10}$. It is important to conduct studies about 
hookworm and Ascaris lumbricoides co-infections, as literature data show the possibility of cross-reaction with Schistosoma mansoni ${ }^{11}$. In this study, we used the KK method (three slides) and the IgG-ELISA technique to detect anti-S. mansoni IgG class antibodies, with the aim of increasing sensitivity in the diagnosis of schistosomiasis in the locality that, according to the PCE, has the highest prevalence of this disease in Ceará, which is an area of low endemicity.

\section{METHODS}

\section{Study area, population, and design}

We conducted a cross-sectional survey in the community of Planalto do Cajueiro, in the municipality of Maranguape, Ceará (in Northeastern Brazil). Maranguape (population 98,429) is located $30 \mathrm{~km}$ from the state capital, Fortaleza, at an altitude of about $736 \mathrm{~m}$. Planalto do Cajueiro is a semi-urban locality, with poor sanitation and infrastructure conditions, and has two small rivers that exhibit populations of the intermediate host Biomphalaria straminea. In the study area, the state's PCE has been conducting KK stool examinations and selective treatment of positive individuals with praziquantel for more than 30 years.

At the time of the survey (2009-2010), Planalto do Cajueiro consisted of 903 inhabitants, with sources of income based primarily on subsistence agriculture and textile/footwear industries. The study included all individuals over two years of age who reside in this town and who agreed to participate, resulting in a target population of 250 individuals. Community meetings were held to explain the objectives of the study. Each household in the community was visited. Family members present on this occasion were interviewed, using pre-tested structured questionnaires.

\section{Stool examinations and ELISA}

For KK stool examinations, labeled plastic containers were distributed for collection of fecal samples. The following day the containers were collected and sent to the local health care center for parasitological examination. Stool samples were prepared in a field laboratory on the same day. To identify S. mansoni eggs, approximately $50 \mathrm{mg}$ of feces were prepared using the KK method (Helm-Test Kit). The intensity of infection, expressed as eggs per gram (epg) of feces, was calculated by multiplying each slide count by 24 . To identify other intestinal helminth eggs, the Lutz method was used ${ }^{12}$.

For the ELISA testing, venous blood was collected using a commercially available system (Becton Dickinson Vacutainer Systems, Franklin Lakes, USA). To detect $S$. mansoni IgG antibodies from serum samples, we used adult worm antigen (SWAP) of S. mansoni and performed ELISA testing according to standard procedures ${ }^{13}$. The cut-off was defined based on the mean value of the optical density $(\mathrm{OD}) \pm 2$ standard deviations $(\mathrm{SD})$ in a base population $(\mathrm{n}=35)$ from the City of Fortaleza with negative parasitological fecal examination. To reduce disturbance of the study population, we did not repeat fecal examinations in the case of positive KK results. OD was measured on an ELISA automatic reader (BioTeck" $/$ USA), using a 490-nm filter.

\section{Statistical analysis}

Data were entered using an Excel $^{\circledR}$ spreadsheet and checked for entry-related errors, by comparing data entries with original data forms. Then data were transferred to software GraphPad PRISM Version 5.0 for analysis.
The sensitivity and specificity as well as the positive predictive value (PPV) and negative predictive value (NPV) of IgG-ELISA were calculated by taking the result of the Kato-Katz examination as the "reference standard."

To reduce inter observer variation, all slides were read by a single investigator. To perform quality control, $10 \%$ of slides were randomly selected for cross-reading by a reference microscopist who was blinded to the results of the first reading. Divergence was less than $5 \%$.

\section{Ethical considerations}

The study was approved by the Ethical Review Board of the Faculty of Medicine of the Federal University of Ceará, Brazil (no. 165/09). Informed written consent was obtained from study participants or, in the case of minors, from their legal guardians. In case of S. mansoni infection, a single dose of praziquantel $(60 \mathrm{mg} / \mathrm{kg}$ body weight) was given. Participants with positive fecal examination for intestinal helminths were treated with albendazole $(400 \mathrm{mg} /$ single dose).

\section{RESULTS}

\section{Parasitological examinations}

Of the 250 individuals studied, 100 (40\%) were male and 150 (60\%) were female. The mean age was 25.5 years ( $\mathrm{SD}=17.92$ years). Forty (16\%) individuals were positive for $S$. mansoni eggs. It is worth noting that 32 were positive after reading of the first slide (estimated prevalence $80 \%), 6$ (15\%) were positive on the second slide, and only $2(5 \%)$ were positive on the third slide. Of these 40 individuals, $22(55 \%)$ were male and $18(45 \%)$ were female. The mean age was 19.6 years ( $\mathrm{SD}=11.26$ years). The infection intensity was low (<50epg) in 28 individuals, average (between 50 and 99epg) in 5 individuals, and high (>100epg) in 7 individuals.

In all, 118 (47.2\%) of 250 serum samples were positive for anti-S. mansoni antibodies using the IgG-ELISA technique. The determined cut-off value (reactivity threshold) was 0.283 ( \pm 2 SD). Of the 118 individuals who were ELISA positive, $78(66 \%)$ had three negative KK slides.

The presence of other parasites was detected in 43 (17.2\%) of 250 subjects using the Lutz method. It is worth noting that $19(24.3 \%)$ of 78 samples that were ELISA positive were parasitologically negative for $S$. mansoni. Other parasites were found, namely, Trichuris trichiura in 7 (8.9\%), Taenia sp in $6(7.7 \%)$, hookworm in 4 (5.1\%), Entamoeb a coli in 2 (2.6\%), and Entamoeba hystolitica/Entamoeba dispar, Strongyloides stercoralis, Endolimax nana complex in $1(1.3 \%)$.

\section{Comparative analysis of the methods}

Figure 1 shows the cumulative fraction of subjects that tested positive using the KK method, according to the number of slides examined (sensitivity). With the examination of a single slide, 32 (80\%) infected individuals were detected. This increased to 40 individuals when three slides were examined, a major improvement for detection when aiming to control the disease.

Figure 2 details the results of individuals, according to ELISA and KK results. There were no false-negative ELISA results; ELISA was positive in all 40 cases in which eggs were detected by the KK method.

Of the 78 subjects with positive ELISA and negative KK, $57(73 \%)$ stated in the interview that they never had schistosomiasis 


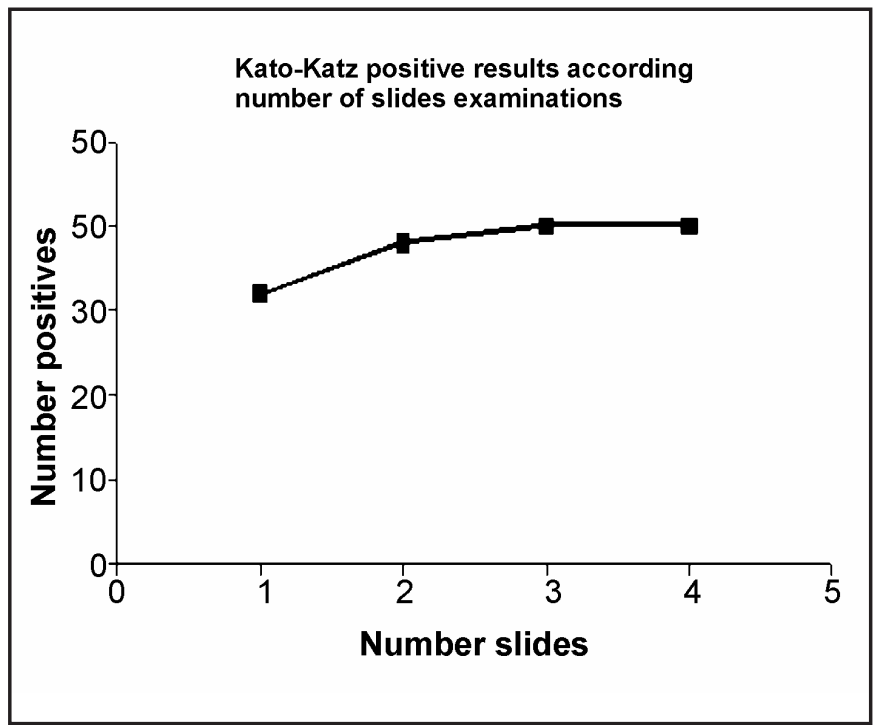

FIGURE 1 - KK-positive results, according to the number of slides examined $(n=40)$. Slides 1-3: one stool sample.

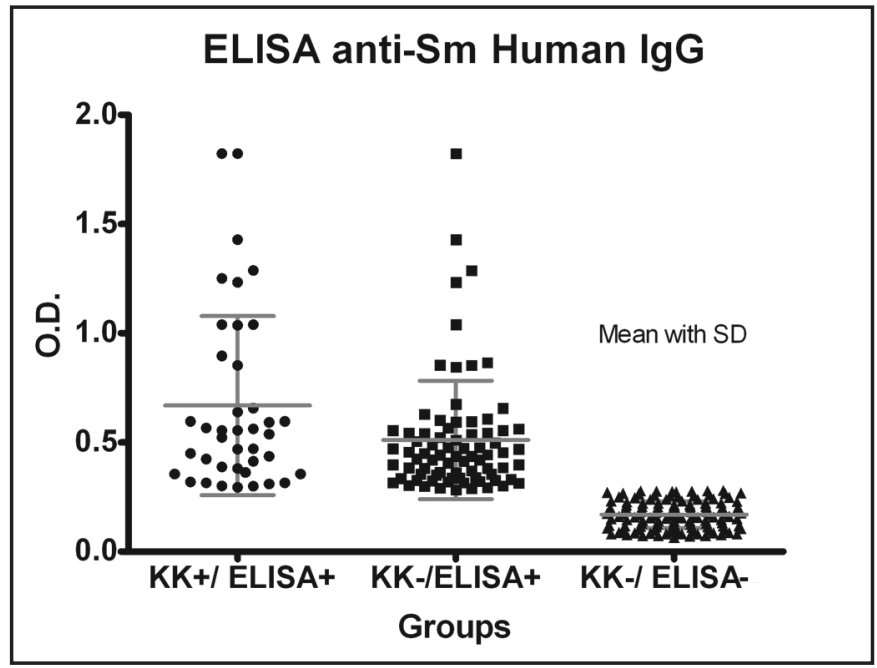

FIGURE 2 - Distribution of individuals according to results of fecal examinations (KK) and ELISA tests $(\mathbf{n}=\mathbf{2 5 0})$. In all individuals with negative ELISA test, KK was negative.

KK: Kato-Katz; ELISA: enzyme-linked immunoabsorbent assay; OD: optical density; SD: standard deviation.

and had never received any specific treatment. The performance of the ELISA test in the diagnosis using the KK method as a diagnostic reference showed that the negative predictive value of the ELISA test was $100 \%$; specificity was $62.8 \%$, and positive predictive value was $33.9 \%$.

\section{DISCussion}

Since 1976, parasitological testing of feces has been used by state schistosomiasis control programs as a criterion for selective treatment with praziquantel ${ }^{14}$. The worldwide methodological strategy currently applied for the diagnosis of mansoni schistosomiasis, using the KK method with one sample and one slide to determine the infection rate, does not have the sensitivity required for such diagnosis and particularly in areas of low endemicity underestimates the prevalence of this parasitosis ${ }^{15}$. Our data confirm that in areas of low endemicity, the stool test has major value for mass diagnosis and monitoring efforts of control, at least when the number of slides is increased.

Increasing the number of KK smears per sample and/or the number of stool samples analyzed increases sensitivity considerably. Enk et al. ${ }^{16}$ demonstrated an increase in the estimated prevalence from $13.8 \%$ (one slide) to $19 \%$ (six slides) using a single stool sample. In this study, seeking to minimize the difficulties that come with repeated collection of stool samples, we worked with one fecal sample as well and analyzed three slides. Using this strategy, we observed an increase in the sensitivity of the KK method, from 32 (12.8\%) of 250 subjects when analyzing one slide, to 40 (16\%) of 250 when analyzing three slides.

Consecutive stool examinations may present logistical problems and higher costs ${ }^{17}$, as well as the need to increase the number of practitioners in the field. Thus, the strategy of increasing the number of slides, from one to three, from a single stool sample is shown to be easily applied in routine of the PCE, since even with limited infrastructure and human resources, the strategy can be applied with no considerable financial or logistical increase in the public healthcare sector.

The number of eggs per slide of the 40 individuals who tested positive for $S$. mansoni, i.e., the individual parasite load, varied from 8 epg to 560epg, with an average of 58epg ( $\mathrm{SD}=93 \mathrm{epg}$ ). Thus, we verified that this region, despite being an area of low endemicity, had individuals with elimination of eggs greater than 100epg.

The introduction of serological methods in epidemiological studies, thus identifying potential infection sites, may contribute to reducing transmission in low endemic areas ${ }^{18}$. In Planalto do Cajueiro, we observed that 118 (47.2\%) of the 250 individuals analyzed were positive using the IgG-ELISA method; similar data were obtained by da Frota et al. ${ }^{8}$ in the community of Caititú de Cima (also in the State of Ceará), where 96 (33.4\%) of 287 subjects were serum reactive.

When we compared the serology results with the parasitology results, we found that the rates of seropositivity were higher (nearly three times greater) than the rates obtained by the KK method. In the 250 individuals evaluated, 118 (47.2\%) were seropositive, whereas only $40(16 \%)$ were parasitologically positive. In this seropositivity there is certainly a portion of individuals who have been cured with treatment, since the technique does not distinguish between active and past infections ${ }^{10}$, and another portion that represents the non-specificity of test, which can occur due to frequent similarity between the constituent antigens of the parasite ${ }^{19}$. In this context, to analyze cross-reactivity, we detected 43 of 250 individuals with the presence of other parasites, using the Lutz method. Studies conducted in Brazil and Venezuela show that sera from patients infected with hookworm and A. lumbricoides exhibit significant cross-reactivity with antigens of S. mansoni ${ }^{11,20}$.

Nevertheless, the immunological methods for diagnosing schistosomiasis take on greater importance every day, and their inclusion in control programs in low endemic areas is crucial ${ }^{21}$. In previous studies in low endemic areas, in which the positivity rates of immunological and parasitological methods were compared ${ }^{22-24}$, the positivity rates of immunological methods were two to six times higher than those of parasitological methods.

The methods of serological and parasitological diagnosis are complementary ${ }^{25}$. When only the stool parasitology method is used to diagnose schistosomiasis, the true prevalence of the disease is underestimated, because of the low efficiency of this method in detecting cases with a small number of eggs. The possibility of 
preselecting individuals to be submitted to the parasitological stool examination, by using a serological technique proven to be more sensitive, allows practitioners to confirm the infection through the insistence of parasitological exam and thereby determine a rate of prevalence closer to reality ${ }^{14}$.

Our study was subject to limitations. It is important to conduct a study with an exhaustive search for eggs in fecal material, mainly in ELISA-reactive individuals without parasitological confirmation who exhibit hookworm infection, seeking to analyze possible crossreactivity. Thus, the interpretation of $100 \%$ sensitivity of the ELISA technique must be taken with caution. Furthermore, a considerable number of individuals from the locality did not provide stool samples, which may produce an underestimation of the prevalence of schistosomiasis in the area.

\section{Conclusions}

We conclude that the increase from one to three slides analyzed per sample using the KK method proved to be a useful tool for increasing the sensitivity of this technique. It is worth noting that although the IgG-ELISA technique is not capable of reliably distinguishing individuals infected with $S$. mansoni from uninfected individuals (as KK is capable of doing), it has been shown to be useful as a screening method, which allows the reduction of the workload for reading several KK slides, mainly in areas of low endemicity. Such a technique is essentially an association of various diagnostic methods available, not only parasitological but also serological and molecular, aimed at detecting the actual prevalence of the disease. The diagnostic potential and applicability of other more sensitive and possibly more specific methods, such as polymerase chain reaction and FLOTAC, need to be assessed systematically in future studies ${ }^{26-28}$.

\section{ACKNOWLEDGMENTS}

The authors are grateful to the Health Secretariat of Maranguape city and Health Secretariat of Ceará State, for their cooperation in the study.

\section{CONFLICT OF INTEREST}

The authors declare that there is no conflict of interest.

\section{REFERENCES}

1. World Health Organization [Internet]. Schistosomiasis disease information 2010. [Cited 2011 Sep 2011]. Available from: http://www.who.int/tdr/diseases schisto/direction.html.

2. Katz N, Chaves A, Pellegrino JP. A simple device for quantitative stool thick-smear in Schistosoma mansoni. Rev Inst Med Trop 1972; 14:397-400.

3. Teles HM, Teles CS, Ferreira ME, Carvalho FZ, Magalhães LA. Eficiência do diagnóstico coproscópico de Schistosoma mansoni em fezes prensadas. Rev Soc Bras Med Trop 2003; 36:503-507.

4. Utzinger J, Booth M, N’Goran EK, Muller I, Tanner M, Lengeler C. Relative contribution of day-to-day and intra-specimen variation in faecal egg counts of Schistosoma mansoni before and after treatment with praziquantel. Parasitology 2001; 122:537-544.

5. Ebrahim A, El-Morshedy H, Omer E, El-Daly S, Barakat R. Evaluation of the Kato-Katz thick smear and formol ether sedimentation techniques for quantitative diagnosis of Schistosoma mansoni infection. Am J Trop Med Hyg 1997; 57:706-708

6. Alarcon de Noya B, Balzan C, Arteaga C, Cesari I, Noya O. The last fifteen years of schistosomiasis in Venezuela: features and evolution. Mem Inst Oswaldo Cruz 1999; 94:139-146.

7. Bergquist R, Johansen MV, Utzinger J. Diagnostic dilemmas in helminthology: what tools to use and when? Trends Parasitol 2009; 25:151-156.
8. Frota SM, Carneiro TR, Queiroz JAN, Alencar LM, Heukelbach J, Bezerra FSM Combination of Kato Katz faecal examinations and ELISA to improve accuracy of diagnosis of intestinal schistosomiasis in a low-endemic setting in Brazil. Acta Tropica 2010; 120:138-141.

9. Gomes LI, Santos-Marques LH, Enk MJ, Oliveira MC, Coelho PM, Rabelo A. Development and evaluation of a sensitive PCR-ELISA system for detection of schistosoma infection in feces. PLoS Negl Trop Dis 2010; 4:664.

10. Noya BA, Ruiz Guevara R, Colmenares C, Losada S, Noya O. Low transmission areas of schistosomiasis in Venezuela: consequences on the diagnosis, treatment, and control. Mem Inst Oswaldo Cruz 2006; 101:29-35.

11. Geiger SM. Immuno-epidemiology of Schistosoma mansoni infections in endemic populations co-infected with soil-transmitted helminths: Present knowledge, challenges, and the need for further studies. Acta Tropica 2008; 108:118-123.

12. Lutz A. Schistosoma mansoni e a Schistosomatose, segundo observações, feitas no Brasil. Mem Inst Oswaldo Cruz 1919; 11:121-125.

13. Colley DG, Hieny SE, Bartholomew RK, Cook JA. Immune response during human schistosomiasis mansoni and regulatory effect of patient sera on human lymphocytes blastogenic responses to schistosomal antigen preparations. Am J Trop Med Hyg 1977; 26:917.

14. Gargioni C, Silva RM, Thomé CM, Quadros CMS, Kanamura HY. Utilização de método sorológico como ferramenta diagnóstica para implementação da vigilância e controle da esquistossomose no Município de Holambra, São Paulo, Brasil. Cad Saude Publica 2008; 24:373-379.

15. Yu XP, Donnelly CA, Anderson RM, Fu YL, Agnew A. The distribution of Schistosoma japonicum eggs in faeces and the effect of stirring faecal specimens. Trop Med Parasitol 1998; 92:181-185.

16. Enk MJ, Lima AC, Massara CL, Coelho PM, Schall VT. A combined strategy to improve the control of Schistosoma mansoni in areas of low prevalence in Brazil. Am J Trop Med Hyg 2008; 78:140-146.

17. Van Lieshout L, Polderman AM, Deelder AM. Immunodiagnosis of schistosomiasis by determination of the circulating antigens CAA and CCA, in particular in individuals with recent or light infections Acta Trop 2000; 77:69-80.

18. Soares LCB, Dias LCS, Kanamura HY, Oliveira EJ, Ciaravolo RM. Schistosomiasi mansoni: Follow-up of Control program based on parasitologic and serologic methods in a Brazilian community of low endemicity. Mem Inst Oswaldo Cruz 2003; 98:853-859.

19. Doenhoff MJ, Chiodini PL, Hamilton JV. Specific and sensitive diagnosis of schistosome infection: can it be done with antibodies? Trends Parasitol 2004, 20:35-39.

20. Corrêa-Oliveira R, Dusse LMS, Viana IRC, Colley DG, Carvalho OS, Gazzinell G. Human antibody responses against schistosomal antigens. Am J Trop Med Hyg 1988; 38:348-355.

21. Noya BA, Balzan C, Artega C, Cesari I, Noya O. The last fifteen years of schistosomiasis in Venezuela: features and evolution. Mem Inst Oswaldo Cruz 1999; 94:136-146

22. Dias LCS, Kawazoe U, Glasser CM, Hoshino-Shimizu S, Kanamura HY, Cordeiro JA, et al. Schistosomiasis mansoni in the municipality of Pedro de Toledo (São Paulo, Brazil) where the Biomphalaria tenagophila is the snail host: I. Prevalence in human population. Rev Inst Med Trop 1989; 31:110-118.

23. Doenhoff MJ, Butterworth AE, Hayes RJ, Sturrock RF, Ouma JH, Koech D, et al. Seroepidemiology and serodiagnosis of schistosomiasis in Kenya using crude and purified egg antigens of Schistosoma mansoni in ELISA. Trans Roy Soc Trop Med Hyg 1993; 87:42-48.

24. Eltiro F, YeEbiyo Y, Taylor MG. Evaluation of an enzyme linked immunosorben assay (ELISA) using Schistosoma mansoni soluble egg antigen as a diagnostic too for Schistosoma mansoni infection in Ethiopian schoolchildren. Am J Trop Med Hyg 1992; 95:52-56.

25. Zhou XN, Guo JG, Wu XH, Jiang QW, Zheng J, Dang H, et al. Epidemiology of schistosomiasis in the People's Republic of China, 2004. Emerg Infect Dis 2007; 13:1470-1476.

26. Knopp S, Rinaldi L, Khamis IS, Stothard JR, Rollinson D, Maurelli MP, et al. A single FLOTAC is more sensitive than triplicate Kato-Katz for the diagnosis of low intensity soil transmitted helminth infections. Trans R Soc Trop Med Hyg 2009; 103:347-354.

27. Pontes LA, Dias-Neto E, Rabello A. Detection by polymerase chain reaction of Schistosoma mansoni DNA in human serum and feces. Am J Trop Med Hygiene 2002; 66:157-162

28. Pontes LA, Oliveira MC, Katz N, Dias-Neto E, Rabello A. Comparison of a polymerase chain reaction and the Kato-Katz technique for diagnosing infection with Schistosoma mansoni. Am J Tropic Med Hygiene 2003; 68:652-656. 